\title{
Environmental Factor Contributed to The Onset of Schizophrenia
}

\author{
Yuleni, ${ }^{1}$ Tuti Wahmurti A. Sapiie, ${ }^{2}$ RA. Retno Ekowati ${ }^{2}$ \\ ${ }^{1}$ Faculty of Medicine, Universitas Padjadjaran, ${ }^{2}$ Departement of Psychiatry Faculty of Medicine \\ Universitas Padjadjaran/Dr. Hasan Sadikin General Hospital, Bandung, ${ }^{3}$ Departement of Anatomy, \\ Cell Biology and Physiology Faculty of Medicine Universitas Padjadjaran
}

\begin{abstract}
Background: Schizophrenia is a severe and chronic mental disorder that needs a long term treatment and social support. This condition may results in burden and disturbance in the family and society A number of studies have investigated some environmental factors that may potentially lead to schizophrenia. One of many suspected environmental factors is place of born or grew up. This study was conducted to investigate association between place of born or grew up and age of onset of schizophrenia.

Methods: This analytical study using cross-sectional method was conducted by retrieving data from 72 medical records of hospitalized schizophrenic patients in Dr. Hasan Sadikin General Hospital from OctoberNovember 2013. The variables in this study were age of onset and place (urban or rural) where the patients born or grew-up.The collected data were analyzed using Chi-Square statistical test.

Results: This study discovered that $75 \%$ of subjects were born or grew up in urban area, $68 \%$ of subjects had age of onset at 20-40 years and there was no association between place of born or grew up and age of onset of schizophrenia (p-value was 0.108 ).

Conclusions: More than half subjects were born and grew up in urban, who had age of onset of schizophrenia at 20-40 years and there is no significant association between place of born or grew up and age of onset of schizophrenia.
\end{abstract}

Keywords: Age of onset, environmental factor, rural, schizophrenia, urban

\section{Introduction}

Schizophrenia is a severe mental disorder that influences the cores of human being, which are cognition, emotion, and behavior. The course of schizophrenia is chronic and can be relapsed. Based on the data, $90 \%$ of schizophrenic patients who undergo treatments are in productive age (15-55 years old) $\cdot^{1-5}$

Schizophrenic patients need long term treatment, continual hospitalization and social support. This condition may results in burden and disturbance in the family and society in some way..$^{1-5}$

A number of studies have investigated some environmental factors may potentially lead to schizophrenia. One of many suspected environmental factors is place of born or grew up..$^{6-10}$ Based on study conducted by Vassos et al. ${ }^{11}$ and Pedersen et al. ${ }^{12}$ in Denmark citizens, it is stated that Schizophrenia Relative Risk (RR) with be born in urban area is 2,4. Moreover, from a study conducted by Lewis et al. ${ }^{6}$ it was discovered that the risk of schizophrenia was 1.65 times higher among men who had been grew up in cities, compared to those grew up in rural area. ${ }^{11}$

Around $0.06-1.7 \%$ of the population are suffered from schizophrenia throughout the world. The number of male patients is approximately equal to women. ${ }^{1}$ The disease can affects human in their early childhood, late teens, or early and middle adulthood. Each age group illustrates different pathological component roles in the disease development. Thus, age of onset acts as the main character of schizophrenia to determine the ruling etiology. ${ }^{13-15}$ This study was conducted to investigate the association between place of born or grew up and age of onset of schizophrenia. 


\section{Methods}

This studied using cross-sectional method. It was conducted in Medical Record Installation Centre and Kemuning Building of Dr. Hasan Sadikin General Hospital from OctoberNovember 2013. The data used was secondary data obtained from schizophrenic patients who were being hospitalized in Department of Psychiatric. Medical records used were those dated from January 2012-September 2013, and were selected using total sampling method. Data retrieved from patient's medical records are age of onset which was based on the patient's history. Those who were first diagnosed schizophrenia by physicians and the place where the patients were born and grew up based on the patients' addresses. Permission to use the database was granted by Health Research Ethics Committee from Dr. Hasan Sadikin General Hospital.

From the 230 medical records, 122 patients were age of onset ranging from 12-40 years old, but 50 patients were excluded because of incomplete or absent medical records. Therefore, 72 patients were included in this study. After the data was collected, place of born or grew up were grouped based on the rule of Kepala Badan Pusat Statistik nomor 37 tahun 2010 concerning the classification of urban and rural area in Indonesia into 2 areas; the urban and rural area. Meanwhile, the age of onset was grouped based on human development theory into 2 groups; 12-19 years and 20-40 year. Finally, the data was analyzed using chi-square analysis.

\section{Results}

Sixty eight percent of subjects had age of onset at 20-40 years and 75\% of subjects were born or grew up in urban area (Table 1).

Eighty seven percent of subjects of age of onset at 12-19 years and 69\% of subjects of age of onset at 20-40 years were born or grew up in urban area. This percentage was greater than the percentage of patients who were born or grew up in rural area, both patients who were in the age of onset of 12-19 years and 20-40 years (Table 2).

From the analysis test, it was found that there was not any significant association between born or grew up in urban area with age of onset of schizophrenia p-value is $>0.05$ $(p=0.108)$

\section{Discussion}

The involvement of environmental factors in schizophrenia such as born or grew up in

\section{Table 1 Characteristics of the Subjects}

\begin{tabular}{lcc}
\hline & Frequency & Percentage \\
\hline Age of onset (years) & & 32 \\
$12-19$ & 23 & 68 \\
$20-40$ & 49 & 75 \\
Place of born or grew up & & 25 \\
Urban & 54 & \\
Rural & 18 & \\
\hline
\end{tabular}

Table 2 Comparison Place of Birth or Grew Up based on Age of Onset of Schizophrenia

\begin{tabular}{|c|c|c|c|c|c|}
\hline & \multicolumn{4}{|c|}{ Place of Born or Grew Up } & \multirow{3}{*}{ Total } \\
\hline & \multicolumn{2}{|c|}{ Urban } & \multicolumn{2}{|c|}{ Rural } & \\
\hline & $\mathbf{n}$ & $\%$ & $\mathbf{n}$ & $\%$ & \\
\hline \multicolumn{6}{|c|}{ Age of onset (years) } \\
\hline $12-19$ & 20 & 87 & 3 & 13 & 23 \\
\hline $20-40$ & 34 & 69 & 15 & 31 & 49 \\
\hline Total & 54 & & 18 & & 72 \\
\hline
\end{tabular}


urban area are inspired by nerve development hypothesis. This hypothesis states that environmental or genetic factors, or more likely their complex interaction, during early periods of brain development, can negatively affect adult mental health and contribute in the increasing of possible onset of schizophrenia in late adolescence (17-19 years old) and adulthood. .,15-17 $^{-17}$

Since a study conducted by Leask ${ }^{9}$ (1939) in Chicago, many studies had reported schizophrenia risk which was higher in urban than in rural. This mental disorder was associated with local population density in urban area. ${ }^{18}$ One of them was a cohort study on 690,000 Swedish citizens. The study emphasized that born in urban was related with schizophrenia risk for late onset (hazard ratio 1.24$).{ }^{7}$ Another study by Pedersen et al. ${ }^{12}$ in Denmark citizens stated that schizophrenia Relative Risk with urban born was 2.4. The higher degrees of urbanization, the higher the risk. $^{11}$

The urban risk factor had been recently addressed in several large population. Cohort studies was investigating place of born, grew up, and residence at onset. The developing line of evidence confirmed an association between place of grew up and risk of schizophrenia and suggested that the urban risk factor influences more in early life. ${ }^{6}$

From study by Brown et al. ${ }^{6}$ in a study examining 49.191 male Swedish conscripts. Survey data obtained at conscription were linked to data from the national psychiatric care registry, encompassing 15 years of follow-up". Brown et al. ${ }^{6}$ found that the risk of schizophrenia was 1.65 times higher among men grew up in cities, compared to those grew up in rural area.11 Supported by a study conducted by Pedersen, et al..$^{12}$ reported that an individual, who stay in higher urbanized city for more than 5 years, has 1.4 times higher risk on schizophrenia. An individual living for more than 15 years in the highest urbanized city has 2.75 times higher risk on schizophrenia. They also discovered that moving from rural to urban in childhood and teenager could also increase the risk of schizophrenia. These all demonstrated the relationship existing between urban and schizophrenia. Not only it does relate with urban born, but also with duration of continual or repetitive urban grew up and residence. ${ }^{14}$ However, an observation by Zammit et al. ${ }^{17}$ argued that the low social interaction in urban was the relevant factor in explaining the increase in mental disorders on people growing up in urban area.,19
Apart from urban and rural factors, there were other potential factors. Schizophrenia was also suggested to have relation with flu virus (and some other infections, including toxoplasmosis) during pregnancy particularly in the second trimester, malnutrition on mother during the first trimester, obstetrical complication, brain damage, substance misuse (such as nicotine, drugs, and alcohol), psychology were are also play important roles, such as immigration status, minority ethnic, and socio-economic status. ${ }^{8-10,14}$

However, in this study, there was no association between place of born or grew up and age of onset of schizophrenia. This finding was different with previous studies confirming an association. This difference may be caused by several factors that could not be explained due to the lack information that stated in the medical records.

Limitations of this study were, no control group included and participated in this study, other environmental risk factors such as social and culture contribute to the onset of schizophrenia were not examined in this study. Based on the results, it can be concluded that more than half subjects were born and grew up in urban, who had age of onset of schizophrenia at 20-40 years and from the result statistical test showed that there was no significant association between place of born or grew up and age of onset of schizophrenia.

\section{References}

1. Sapiie TWA. Hubungan reseptor serotonin 5-HT2a trombosit dengan gejala negatif pasien skizofrenia yang mendapat pengobatan kombinasi antipsikotik antagonis D2 dan antidepresan antagonis 5-HT2A [dissertation]. Bandung: Universitas Padjadjaran; 2003.

2. Ascher-Svanum $\mathrm{H}$, Zhu B, Faries DE, Salkever D, Slade EP, Peng X, et al. The cost of relapse and the predictors of relapse in the treatment of schizophrenia. BMC Psychiatry. 2010;10:2.

3. Clemmensen L, Vernal DL, Steinhausen H-C. A systematic review of the long-term outcome of early onset schizophrenia. BMC Psychiatry. 2012;12:150.

4. Haynes VS, Zhu B, Stauffer VL, Kinon BJ, Stensland MD, Xu L, et al. Long-term healthcare costs and functional outcomes associated with lack of remission in schizophrenia: a post-hoc analysis of a prospective observational study. BMC Psychiatry. 2012;12:222. 
5. Kurihara T, Kato M, Reverger R, Tirta IG. Remission in schizophrenia: a community-based 6-year follow-up study in Bali. Psychiatry Clinical Neurosci. 2011;65(5):476-82.

6. Brown AS, Bresnahan M, Susser ES. Schizophrenia: environmental epidemiology. In: Sadock BJ, Sadock VA, editors. Kaplan \& Sadock's comprehensive textbook of psychiatry. 8th ed. Philadelpia: Lipincott Williams \& Wilkins; 2005. p. 1371-5.

7. Murray RM, Bramon E. Developmental model of schizophrenia. In: Sadock BJ, Sadock VA, editors. Kaplan \& Sadock's comprehensive textbook of psychiatry. 8th ed. Philadelpia: Lippincott Williams \& Wilkins; 2005. p. 1381-93.

8. Dean K, Murray RM. Environmental risk factors for psychosis. Dialogues Clin Neurosci. 2005;7(1):69-80.

9. Leask SJ. Environmental influences in schizophrenia: The known and the unknown. Adv Psychiatr Treat. 2004;10(5):323-30.

10. McGrath J, Saha S, Chant D, Welham J. Schizophrenia: a concise overview of incidence, prevalence, and mortality. Epidemiol Rev. 2008;30:67-76.

11. Vassos E, Pedersen CB, Murray RM, Collier DA, Lewis CM. Meta-analysis of the association of urbanicity with schizophrenia. Schizophr Bull. 2012;38(6):1118-23.
12. Pedersen CB, Mortesen PB. Evidence of a dose-response relationship between urbanicity during upbringing and schizophrenia risk. Archiv Gen Psychiatry. 2001;58(11):1039-46.

13. DeLisi LE. The significance of age of onset for schizophrenia. Schizophr Bull. 1992;18(2):209-15.

14. Krabbendam L, Os Jv. Schizophrenia and urbanicity: A major environmental influence-conditional on genetic risk. Schizophr Bull. 2005;31(4):795-9.

15. Kessler RC, Amminger GP, Aguilar-Gaxiola S, Alonso J, Lee S, Ustun TB. Age of onset of mental disorders: a review of recent literature. Current opinion in psychiatry. 2007;20(4):359-64.

16. McGrath JJ, Murray RM. Environmental Risk Factors for Schizophrenia. In: Weinberger DR, Harrison P, editors. Schizophrenia. 3th ed. New York: John Wiley \& Sons; 2011.

17. Zammit S, Lewis G, Rasbash J, Dalman C, Gustafsson J-E, Allebeck P. Individuals, schools, and neighborhood: A multilevel longitudinal study of variation in incidence of psychotic disorders. Arch Gen Psychiatry. 2010;67(9):914-22.

18. March D, Hatch SL, Morgan C, Kirkbride JB, Bresnahan M, Fearon P, et al. Psychosis and Place. Epidemiol Rev. 2008;30(1):84-100.

19. Allardyce J, Boydell J. Environment and schizophrenia: Review: The wider social environment and schizophrenia. Schizophr Bull. 2006;32(4):592-8. 